\title{
How a scientific society progresses - regardless all the craps - to a serious fostering of sustainable medicine
}

\author{
Roberto Nardi \\ Internal Medicine, Maggiore Hospital, Bologna, Italy
}

The crap (so called by some Italian vernacular idioms as fuffa), is a typical light wool that forms in the tissues and which is typically removed as anti-aesthetic. Just this connotation has caused to be used sensu lato in indicating an excess useless. It can also contribute to the definition of accumulation of hair that occur in animals or dust accumulation in cotton balls.

Charlie Brooker, forty-Guardian columnist, journalist, author and TV host, wrote on Sunday $28^{\text {th }}$ July 2013 in his weekly column to feel overwhelmed by all of this continuous chatter that is in the world: an immense cloud of bla-bla which - he admitted - he contributes same. ${ }^{1}$ Everyone is talking at the same time and one on the other; all around the world write words on their computers, forever [...]. The cloud of bla-bla feeds the ego of the writer and enhances the egotistical and narcissistic side of everyone. One of the cornerstones of the west literary and figurative wants that art is truly successful when you do not see when it is concealed, so as to produce an impression of ease, spontaneity, grace, ease, without effort and study. ${ }^{2}$

Many words, but which facts?

In the real world, in fact, the management of complex internal patients needs some pointed new rules and inventions, techniques and creativity, based upon traditions, but also experience and innovations, without any self-accreditation. In 2013 the Federation of Associations of Hospital Doctors on Internal Medicine

Correspondence: Roberto Nardi, via C. Pavese 16/2, 40141

Bologna, Italy.

Tel.: +39.335.8291342

E-mail: nardidoc48@gmail.com

Received for publication: 11 June 2015

Accepted for publication: 11 June 2015.

This work is licensed under a Creative Commons Attribution NonCommercial 3.0 License (CC BY-NC 3.0).

CCopyrigh R. Nardi, 2015

Licensee PAGEPress, Italy

Italian Journal of Medicine 2015; 9:203

doi:10.4081/itjm.2015.612
(FADOI) has published its position statement, to develop a sustainable medicine, based upon the real needs of hospitalized patients in the internal medicine wards. ${ }^{3,4}$ Together with at ANİMO Association of nurses internists, we proposed ten further fundamental points $^{5}$ and, in succession, a Decalogue FADOI for a Slow Medicine by condensing ten points in our vision, just joining the program Slow Medicine entitled Doing more does not mean better. ${ }^{6}$

In such ways as internists, both together doctors and nurses, we all want to contribute to address frugality and sustainability in the public healthcare system. Without unnecessary further words, such as fuffas, craps and bla-bla crowding. With substantial contents.

\section{Roberto Nardi Editor-in-Chief, Italian Journal of Medicine}

\section{References}

1. Brooker C. Too much talk for one planet: why I'm reducing my word emissions; 28 July 2013. Available from: http://www.theguardian.com/commentisfree/2013 /jul/28/too-much-talk-charlie-brooker?INTCMP=SRCH

2. D'Angelo P. Ars est celare artem - Da Aristotele a Duchamp. Macerata: Quodlibet; 2005.

3. Nardi R, Berti F, Fabbri L, et al. Towards a sustainable and wise healthcare approach: potential contributions from hospital Internal Medicine Departments to reducing inappropriate medical spending. Ital J Med 2013;7: 81-97.

4. D'Amore F. The doctor and the patient: doing too much or too little. Ital J Med 2013;7:135-7.

5. Bordin G, Ganzini C, Lince $M$, et al. The ANİMO Decalogue for a Slow Medicine care: the general recommendations of the nurses of internal medicine for a sober, respectful and equitable care. Ital J Med 2015; 9:279-80.

6. Luisiani L, Frediani R, Nardi R, et al. Doing more does not mean doing better: the FADOI contribution to the Slow Medicine program for a sustainable and wise healthcare system. Ital J Med 2015;9:281-6. 